RESEARCH ARTICLE

\title{
An Analysis of the Alignment of Archaeological Sites
}

\section{Mark J. Carlotto}

Submitted July 16, 2019; Accepted October 12, 2019; Published March 30, 2020

https://doi.org/10.31275/2020/1617

Creative Commons License CC-BY-NC

Abstract-There are hundreds, perhaps thousands, of sites of archaeological importance throughout the world. In this study, the alignments of more than two hundred ancient sites were measured and analyzed. Sites are organized into eight geographic regions: South America, Mesoamerica, North America, Europe, the Middle East, Africa, Asia, and the Pacific Ocean. Google Earth imagery and measurement tools were used to estimate the alignment of linear and rectilinear structures at these sites with respect to true (geographic) north. In considering standard celestial and geographic reasons for the alignments, many were found to be oriented to the cardinal directions, in the directions of solstices and other solar events, to lunar standstills, and to certain stars. A number of sites in China and Thailand were likely aligned to magnetic north at the time of construction using a compass. Some sites appear to have been aligned to "sacred directions" that include Islamic qibla and Quechua ceques. Site-alignment statistics reveal similarities and differences between geographical regions in terms of how sites within regions are aligned. Perhaps the most unexpected finding is that the alignment of about half of the sites could not be explained in terms of any of the explanations considered.

Keywords: archaeoastronomy; solstices; archaelogical alignment; sacred places; sacred directions; lunar standstills

\section{INTRODUCTION}

Evidence throughout the world suggests that human civilizations have a tendency to build their cities, and sacred and other places of importance, in specific directions. Many of the oldest pyramids and temples are aligned to the cardinal directions-north, south, east, and 
west, sometimes with uncanny precision, such as the pyramids on the Giza plateau in Egypt (Lehner, 1997). The Angkor temples in Thailand (Magli, 2016) and certain earthen mounds in China also are aligned to the cardinal directions, as were early Chinese cities (Sparavigna, 2013). Although the cardinal directions can be determined readily from the motion of the sun and stars, there is evidence that the Chinese used the magnetic compass in some cases to align places of importance based on principles of geomancy and Feng Shui (Charvátová et al. 2011).

There are many places that are aligned to the cycles of the sun and moon, specifically to the northernmost and southernmost rising and setting of the sun and moon, called solstices and lunar standstills, respectively. Stonehenge is aligned both to solstices and to lunar standstills (Hawkins, 1965). Some Egyptian temples, most notably the Temple of Amun-Re at Karnak, are aligned to the winter solstice sunrise/ summer solstice sunset (Shaltout \& Belmonte, 2005). The head of the Great Serpent Mound in Ohio points toward the summer solstice sunset (Hardman \& Hardman, 1987). Some of the most sacred places on earth are aligned to the moon, including the Kaaba in Mecca (Hawkins \& King, 1982) and the Golden Temple in Amritsar.

There is evidence that some sites may have been aligned to the point on the horizon where certain stars and planets of importance once rose. Examples include the ancient city of Teotihuacan, north of Mexico City, thought to be aligned to the Pleiades (Aveni, 2001) and the Temple of Hathor at Dendera in Egypt, aligned to Alkaid, a star in Ursa Major (Shaltout \& Belmonte, 2005). The Caracol at Chichen Itza is believed to have been oriented to observe the planet Venus.

The misalignment of certain places with respect to the cardinal directions has been explained in terms of local factors including topography and landscape. A part of Mexico City surrounding the ancient Aztec capital of Tenochtitlan is aligned in a direction slightly south of east. One theory is that the site was rotated in order to compensate for the shift in the position of the sun when it rose over Templo Mayor on the equinox rather than directly east at the horizon (Aveni et al., 1988). Ridderstad (2009) proposes a number of reasons why Knossos on the island of Crete is misaligned by about $10^{\circ}$ south of east.

Finally, there are sites aligned toward places of spiritual importance. Today many mosques face toward Mecca. However, there are 
other sacred directions called qibla that are also used to align mosques (King, 2018). In Peru, imaginary lines known as ceques (Krupp, 1994) emanate out from the center of the city of Cuzco in all directions, one of which passes through the Inca fortress of Sacsayhuamán.

This paper analyzes the alignments of more than two hundred archaeological sites from across the world. The next section, Alignment Hypotheses, defines eight hypotheses against which alignments are assessed. The following section, Alignments of Archaeological Sites, presents our findings organized by geographic region. And the last section, Analysis of Alignments, summarizes the results of our analysis. Based on the distribution of site alignments, we show that there are interesting similarities and differences among geographic regions. Surprisingly, the alignment of about half of the sites considered in this study cannot be explained by any of the hypotheses considered.

\section{ALIGNMENT HYPOTHESES}

From a review of the archaeological and archaeoastronomical literature, eight basic explanations were identified to account for the orientation of an archaeological site: 1 ) to cardinal directions (i.e. facing north, south, east, and west), 2) to solstice sunrise or sunset directions, 3) to sunrise or sunset directions on days when the sun passes directly overhead, 4) to directions of major and minor lunar standstills, 5) to a planet, 6) to a star or constellation, 7) to magnetic north, and 8) in the direction of an earth site of religious or spiritual importance. We also discuss other explanations such as landscape and topography.

\section{Cardinal Directions}

The cardinal directions can be established either by observing the motion of stars at night or the path of the sun during the day or over the course of the year. A site aligned to the cardinal directions faces sunrise and sunset twice a year on the spring and autumn equinoxes.

\section{Solstices}

Many ancient sites reference the directions of the sun on the first day of summer and winter (solstices). To determine if a site is aligned to the solstices, define the following angles: 
$\alpha-$ azimuth angle of the sun (measured clockwise with respect to true north),

$\theta$ - elevation angle of the sun above the horizon,

$\phi$-latitude of the site,

$\delta$ - solar declination. The tilt of the earth on its axis, the obliquity, $\varepsilon$, is what causes the seasons.

The solar declination is the tilt of the earth toward the sun, which varies with the season, $-\varepsilon \leq \delta \leq \varepsilon$, reaching its largest and smallest values on the summer and winter solstices, respectively. On the spring and fall equinoxes, $\delta=0^{\circ}$.

The following solar path equation (Figure 1) relates the solar azimuth, the solar elevation, the latitude of the site, and the solar declination:

$$
\cos \alpha=(\sin \delta-\sin \theta \sin \phi) / \cos \theta \cos \phi
$$

and can be used to calculate the azimuth angle of the sun at sunrise and sunset on the summer solstice

$$
\begin{aligned}
& \alpha_{s \uparrow}=\cos ^{-1}(\sin \delta / \cos \phi) \\
& \alpha_{s \downarrow}=-\cos ^{-1}(\sin \delta / \cos \phi)
\end{aligned}
$$

and on the winter solstice:

$$
\begin{gathered}
\alpha_{w \uparrow}=\cos ^{-1}(-\sin \delta / \cos \phi) \\
\alpha_{w \downarrow}=-\cos ^{-1}(-\sin \delta / \cos \phi)
\end{gathered}
$$

The obliquity changes slowly over time, less than $2^{\circ}$ over a period of 41,000 years. The present value is $23.43^{\circ}$. Due to changes in obliquity, solar alignments established in the distant past no longer line up exactly. By inverting Equation 1 we can determine when an alignment at a given angle would have lined up with a solstice or some other event by solving for the obliquity as a function of azimuth angle at sunrise or sunset:

$$
\delta=\sin ^{-1}(\cos \alpha \cos \phi)
$$




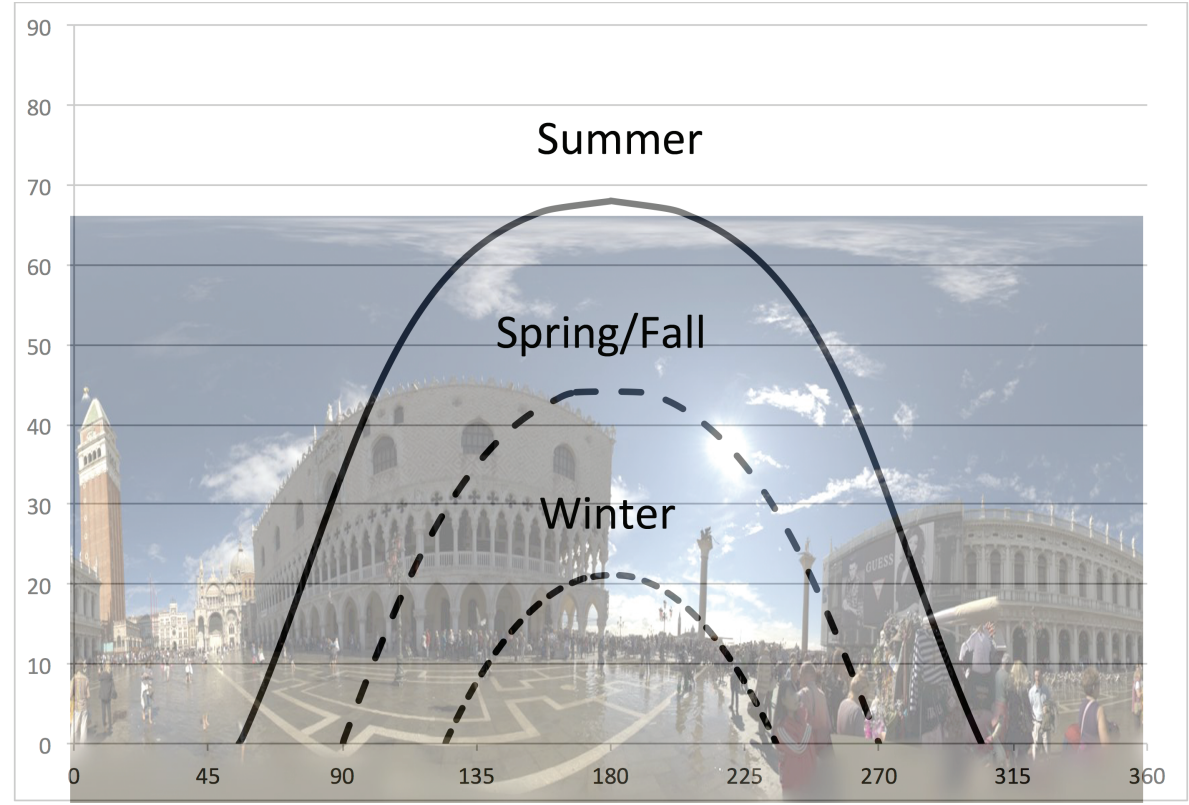

Figure 1. Seasonal path of the sun (Equation 1) plotted over panoramic photo facing south taken at Piazza San Marco, Venice. Photo credit: https://www.openfootage.net/Openfootage/Vorschau/ContactSheet_ Piazza-San-Mar.jpg

It is noted that these equations do not take into account the local horizon, which may be affected by mountains and hills that cause the sun and moon to rise later and set earlier than over a flat horizon, and do not model atmospheric refraction that affects the appearance of celestial objects close to the horizon, both of which can be important factors in the alignment of certain sites.

\section{Zenith Passage}

At the equator, the sun passes directly overhead at noon on the equinox. Within the zone of the tropics, the sun can still pass overhead on certain other days. This occurs on days when the solar inclination is equal to the site's latitude. An alignment occurs either at sun rise or sunset when

$$
|\phi|=90^{\circ}-|\alpha|
$$




\section{Lunar Standstills}

The plane of the moon's orbit is tilted by $5.1^{\circ}$ relative to the ecliptic. Because of its orbit, the moon can rise and set more northerly and more southerly than the sun. Due to the effects of the sun's gravity, the moon's orbital plane does not stay fixed in space but precesses, causing the monthly angles of moonrise and moonset to change over an 18.6year cycle. Every 18.6 years the moon rises at its maximum northerly direction, which is known as a major lunar standstill. A minor lunar standstill occurs 9.3 years later when the moon rises at its minimum northerly direction. The moonrise and moonset azimuth angles at a standstill are

$$
\begin{aligned}
& \alpha_{m \uparrow}=\cos ^{-1}(\sin \mu / \cos \phi) \\
& \alpha_{m \downarrow}=-\cos ^{-1}(\sin \mu / \cos \phi)
\end{aligned}
$$

where $\mu$ is the lunar declination which is $\mu= \pm\left(\varepsilon+5.1^{\circ}\right)$ for a major standstill and $\mu= \pm\left(\varepsilon-5.1^{\circ}\right)$ for a minor standstill.

Figure 2 shows several examples of sites aligned to the sun and moon.

\section{Planetary Alignments}

The motion of the planets is along the imaginary line defined by the plane of earth's orbit around the sun known as the ecliptic. As a result, a planet can appear to rise anywhere between the summer and winter solstice sunrise directions and set anywhere between the summer and winter solstice sunset directions. For example, the maximum northern and southern setting directions of Venus observed at the Caracol in Chichen Itza are the same as the solstice sunset directions.

\section{Stellar Alignments}

It is convenient to think of the stars existing on the inside of a celestial sphere. As earth revolves on its axis, stars appear to rotate around the celestial poles. In addition to obliquity, the earth's axis precesses in a 26,000-year cycle about the ecliptic pole. The direction in which a star rises and sets on the horizon depends on its location on the celestial sphere, the latitude of the site where it is observed, and the time of observation with respect to the precessional cycle. 


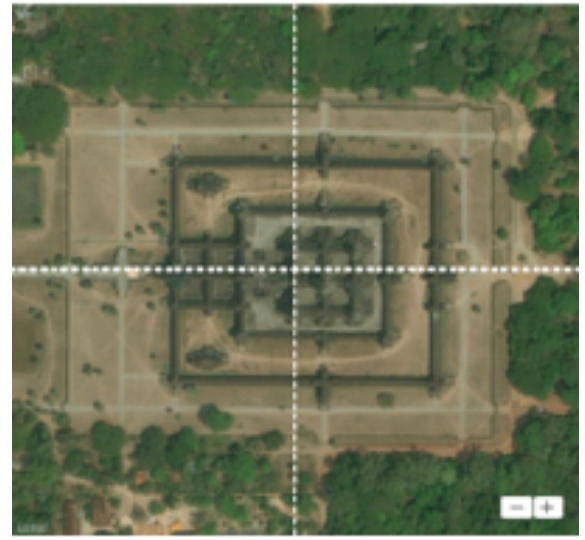

A) Angkor Wat-Cardinal Directions

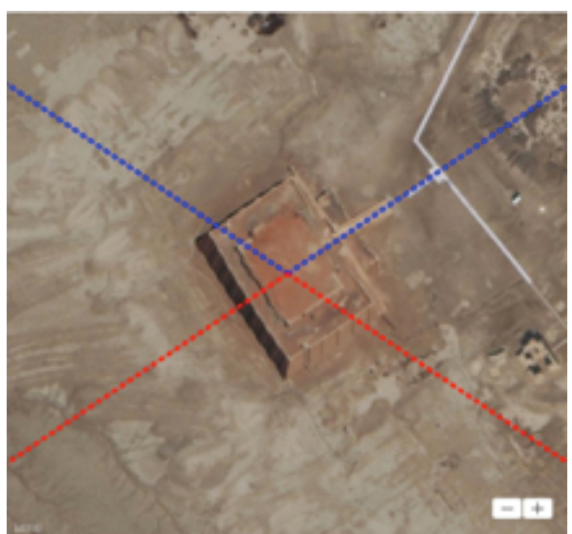

C) Ziggurat of Ur-Major Lunar Standstills

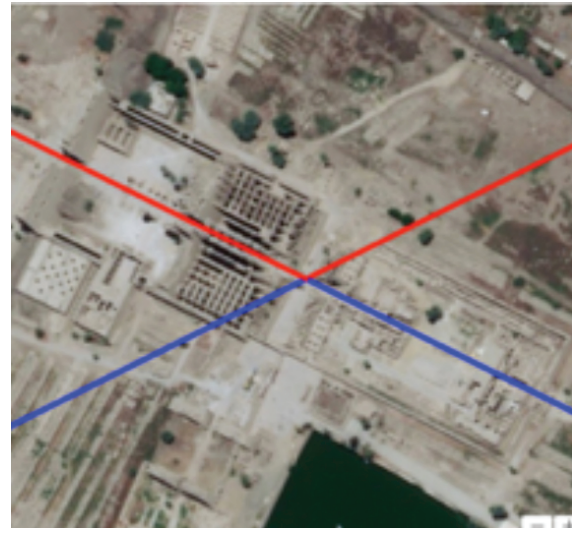

B) Karnak-Solstices

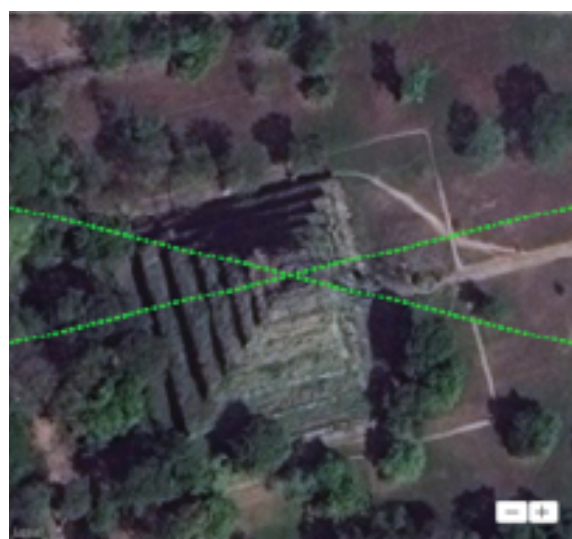

D) Koh Ker-Zenith Passage

Figure 2. Examples of sites aligned to the sun and moon. There are two sets of lines in B) through D), since solstices, lunar standstills, and zenith passages occur twice a year. Photo credit: Apple Maps.

\section{Alignments to Magnetic North}

There is evidence that ancient sites in certain parts of the world were aligned using a magnetic compass. Unlike the geographic poles, the magnetic pole is constantly in motion (Figure 3). In order to determine the alignment of a site to a pole (or any reference location on the surface of the earth), let $A, B$, and $C$ be the locations of a site, the geographic North Pole, and the magnetic pole at a given time, respectively (Figure 4). 

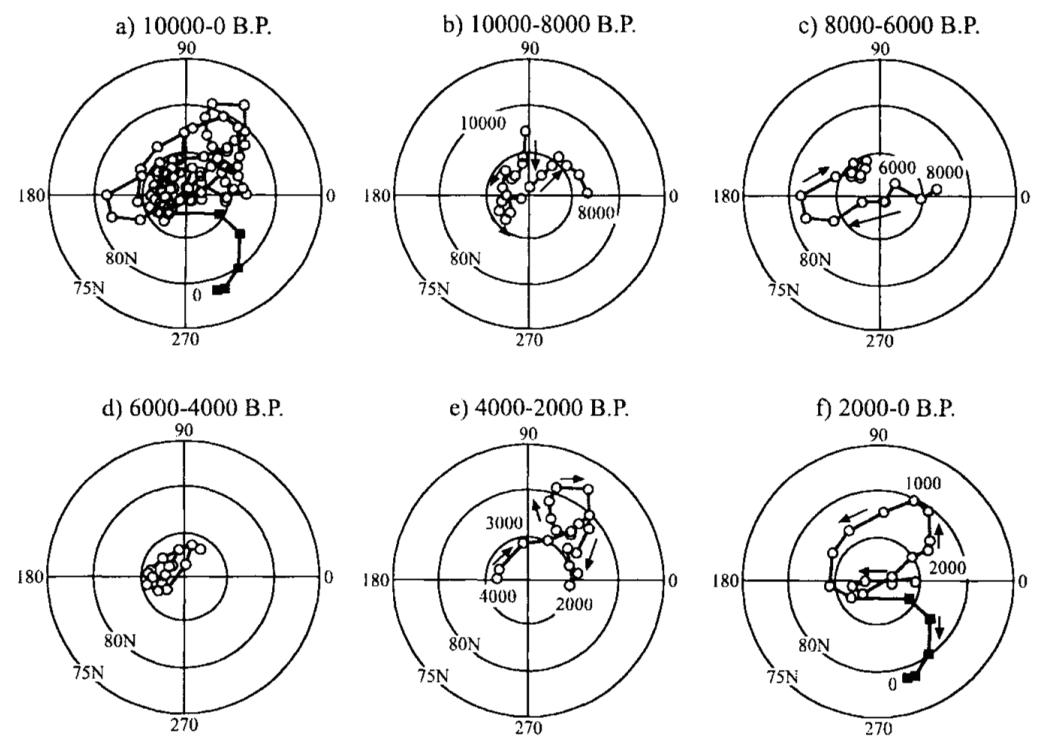

Figure 3. Estimated locations of the north geomagnetic pole over the past 10,000 years (from McElhinny \& McFadden, 2000).

If $\left(\lambda_{A}, \varphi_{A}\right)$ and $\left(\lambda_{C}, \varphi_{C}\right)$ are the latitudes and longitudes of the site and reference locations, define the angles

$$
\begin{aligned}
& a=\frac{\pi}{2}-\lambda_{C} \\
& c=\frac{\pi}{2}-\lambda_{A} \\
& B=\varphi_{C}-\varphi_{A}
\end{aligned}
$$

We wish to solve for the angle $A$ (the azimuth angle of the reference location from the site) as a function of the locations of $A$ and $C$ on the sphere. Starting with the sine and cosine rules for spherical triangles:

$$
\frac{\sin A}{\sin a}=\frac{\sin B}{\sin b}=\frac{\sin C}{\sin C}
$$

and

$$
\cos b=\cos a \cos c+\sin a \sin c \cos B
$$




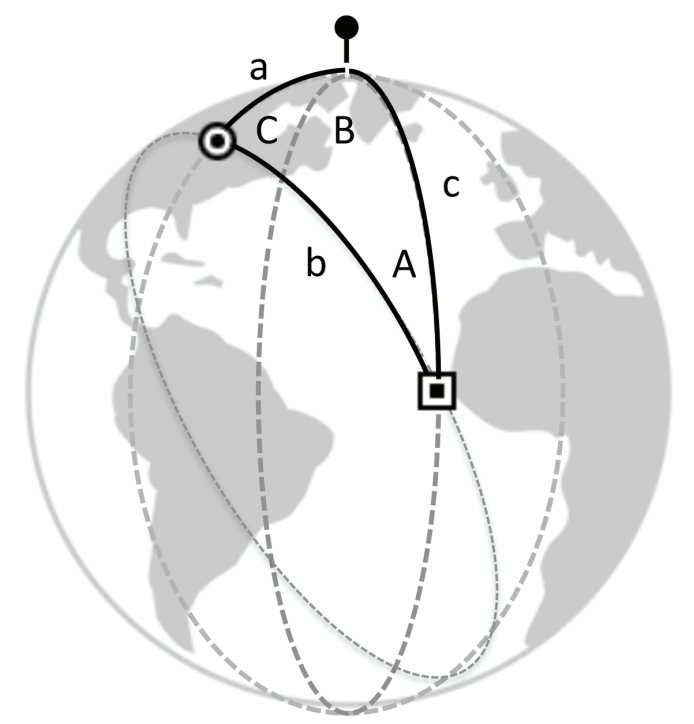

Figure 4. The locations of a site A, North Pole $B$, and reference $C$ are the vertices of a spherical triangle. Edges of spherical triangles are great circles. The angle $A$ is the azimuth of the reference location measured at the site.

since $\sin b=\sqrt{1-\cos ^{2} b}$

$$
\begin{gathered}
\sin A=\frac{\sin a \sin B}{\sin b}=\frac{\sin a \sin B}{\sqrt{1-\cos ^{2} b}} \\
A=\sin ^{-1}\left[\frac{\sin a \sin B}{\sqrt{1-(\cos a \cos c+\sin a \sin c \cos B)^{2}}}\right]
\end{gathered}
$$

Using the estimated location of the north geomagnetic pole at a given time, it is possible to approximate the compass direction of magnetic north at a site at that time (Figure $5 \mathrm{~A}$ ).

\section{Alignments to "Sacred Directions"}

As noted above, Equation 11 can compute the azimuth angle at any location to any other location on the surface of the earth and can be used to evaluate alignments to "sacred directions" that include Islamic 


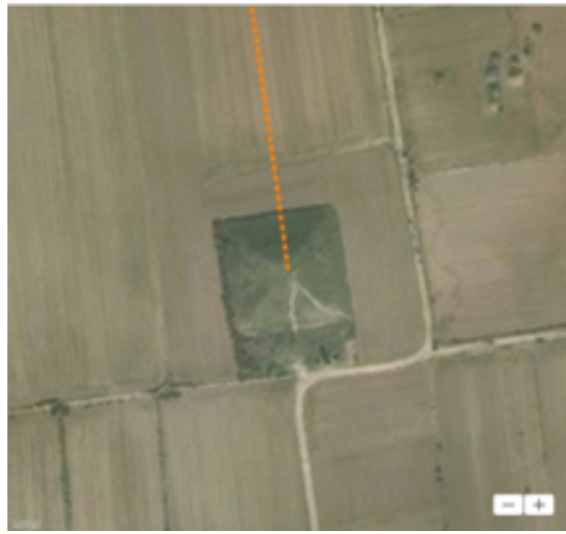

A) Chongling Mausoleum of Emperor Dezong of Tang aligned to geomagnetic pole at $83^{\circ} \mathrm{N} 45^{\circ} \mathrm{E}$.

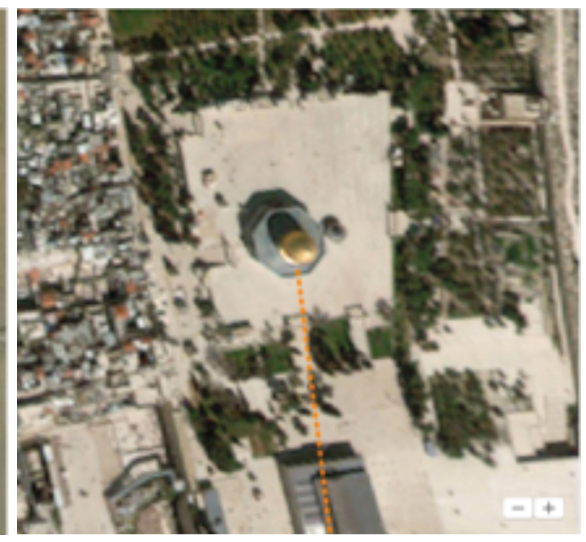

B) Dome of the Rock in Jerusalem faces Petra.

Figure 5. Sites aligned in other directions.

qibla and Quechua ceques (Lon, 2005). For example, using Equation 11 it can be determined that the Rock of the Dome in Jerusalem is aligned in the direction of Petra in Jordan (Figure ${ }_{5} \mathrm{~B}$ ).

\section{ALIGNMENTS OF ARCHAEOLOGICAL SITES}

The selection of archaeological sites from across the world is a challenging exercise in itself. More than two hundred sites were identified from a variety of sources including UNESCO's World Heritage Center, Wikipedia, Google Earth, and scientific and popular literature. The selected sites contain linear and rectilinear structures that are wellresolved and visible in overhead imagery. Google Earth imagery and measurement tools were used to measure heading (azimuth) angles. Alignments are indicated in Tables 1-8 according to the following key:

Cardinal directions, i.e. geographic poles, and equinoxes (E) Magnetic pole at the time of construction $(X)$

Zenith passage $(Z)$

Solstices (S)

Major and minor lunar standstills $(M, m)$

Stellar alignments (st)

Alignments to "sacred directions" (D) 
Measured angles of rectangular structures and rectilinear features are listed two ways: by a NW to NE facing angle between $-45^{\circ}$ and $+45^{\circ}$, and a NE to SE facing angle between $45^{\circ}$ and $135^{\circ}$.

In a previous aerial archaeological study using Google Earth (Lepionka \& Carlotto, 2015), heading measurement errors were found to be as small as $0.1^{\circ}$ between widely spaced, well-defined, point-like features. Measurement errors at some of the sites considered here could be somewhat higher, particularly for ruined structures that lack a welldefined edge and for smaller structures with short edges. In this study, a structure is classified as being in alignment with a cardinal or other direction if the sides of the structure are within approximately $1^{\circ}$ of that direction. For solar and lunar alignments, a site is considered aligned to a solstice or lunar standstill if a structure at the site, or an alignment between structures at the site, is within the range of solstice or lunar standstill directions at that latitude over the earth's 41,000-year obliquity cycle.

In general the alignment hypotheses represent eight mutually exclusive directions or ranges of direction at a particular site (although at certain latitudes minor lunar standstill moonrise/moonset directions and zenith passage sunrise/sunset directions can overlap). In addition to these eight alignment hypotheses (plus "unknown"), there are sometimes other explanations for the alignment of the site as noted in the tables and discussed in the accompanying text.

\section{Africa}

Table 1 lists the sites examined in Africa, most of which are in Egypt. About half of the sites are aligned to the cardinal directions. Most of these are pyramids in Lower Egypt. Shaltout and Belmonte (2005) analyzed the orientation of more than one hundred temples in Upper Egypt and Lower Nubia to discover that they face many different directions with a somewhat greater concentration of alignments in the east-southeast direction. This is in agreement with our finding of sites aligned to solstices and major and minor lunar standstills. Their principal conclusion is that local topography (the course of the Nile River) was more important than astronomy in aligning the foundations of the temples. Our finding that half of the sites examined in Egypt do not appear to be aligned to obvious astronomical events is consistent 
TABLE 1

Alignments of Sites in Africa

\begin{tabular}{|c|c|c|c|c|c|}
\hline Name & Latitude & Longitude & North & East & Alignment \\
\hline Algeria, Jabal Lakhdar & 35.063404 & 1.183731 & -5 & 85 & \\
\hline Egypt, Abu Rawash, Pyramid of Djedefre & 30.032262 & 31.074714 & 0 & 90 & $\mathrm{E}$ \\
\hline Egypt, Abusir, Pyramid of Neferefre & 29.893770 & 31.201454 & 0 & 90 & $\mathrm{E}$ \\
\hline Egypt, Abusir, Pyramid of Neferirkare & 29.895093 & 31.202249 & 0 & 90 & $\mathrm{E}$ \\
\hline Egypt, Abusir, Pyramid of Sahure & 29.897622 & 31.203367 & 0 & 90 & $\mathrm{E}$ \\
\hline Egypt, Abydon, Temple Ramses II & 26.186426 & 31.916280 & 44.2 & 134.2 & \\
\hline Egypt, Abydos, Osirion & 26.184099 & 31.918465 & 36.3 & 126.3 & \\
\hline Egypt, Abydos, Pyramid of Ahmose I & 26.175056 & 31.937822 & 36 & 126 & \\
\hline Egypt, Abydos, Temple Seti I & 26.184968 & 31.919183 & 36.3 & 126.3 & \\
\hline Egypt, Cairo, Mosque of Ibn Tulun & 30.028691 & 31.249394 & -39 & 51 & \\
\hline Egypt, Dahshur Pyramid of Senusret III & 29.818888 & 31.225550 & 0 & 90 & $\mathrm{E}$ \\
\hline Egypt, Dahshur, Bent Pyramid & 29.790449 & 31.209324 & 0 & 90 & $\mathrm{E}$ \\
\hline Egypt, Dahshur, Pyramid of Amenemhat II & 29.805807 & 31.223038 & 0 & 90 & $\mathrm{E}$ \\
\hline Egypt, Dahshur, Red Pyramid & 29.808882 & 31.206113 & 0 & 90 & $\mathrm{E}$ \\
\hline Egypt, Deir Bahari, Mortuary Temple of Mentuhotep II & 25.737375 & 32.606178 & 23.2 & 113.2 & $s$ \\
\hline Egypt, Deir el Medinah, Temple of Hathor & 25.728846 & 32.602128 & -40 & 50 & \\
\hline Egypt, Dendara, Sacred Lake & 26.141807 & 32.669532 & 16.1 & 106.1 & \\
\hline Egypt, Dendera, Temple of Hathor & 26.141914 & 32.670205 & 18.9 & 108.9 & st, $\mathrm{m}$ \\
\hline Egypt, Edfu Temple of Horus & 24.976747 & 32.873087 & 12.8 & 102.8 & \\
\hline Egypt, Elephantine, Temple of Khnum & 24.084492 & 32.886206 & -42 & 48 & \\
\hline Egypt, Giza, Khafre & 29.975726 & 31.130800 & 0 & 90 & $\mathrm{E}$ \\
\hline Egypt, Giza, Khufu & 29.979067 & 31.134040 & 0 & 90 & $\mathrm{E}$ \\
\hline Egypt, Giza, Menkaure & 29.975811 & 31.131242 & 0 & 90 & E \\
\hline Egypt, Kom Ombo & 24.452085 & 32.928353 & 43.3 & 133.3 & \\
\hline Egypt, Lisht, Pyramid of Amenemhat I & 29.574802 & 31.225304 & 0 & 90 & $\mathrm{E}$ \\
\hline Egypt, Lisht, Pyramid of Senusret I & 29.560160 & 31.221130 & 0 & 90 & $\mathrm{E}$ \\
\hline Egypt, Luxor West, Temple Ramses III & 25.719683 & 32.600711 & -42 & 48 & \\
\hline Egypt, Luxor, Karnak, Temple of Amun Re & 25.718484 & 32.659044 & 26.6 & 116.6 & S \\
\hline Egypt, Meidum Pyramid & 29.388368 & 31.157503 & 0 & 90 & $\mathrm{E}$ \\
\hline Egypt, Pyramid of Teti & 29.875142 & 31.221847 & -12.5 & 77.5 & \\
\hline Egypt, Saqqara, Mastaba of Shepseskaf & 29.838852 & 31.215273 & 0 & 90 & $\mathrm{E}$ \\
\hline Egypt, Saqqara, Pyramid of Djedkare-Isesi & 29.850983 & 31.220924 & 0 & 90 & $\mathrm{E}$ \\
\hline Egypt, Saqqara, Pyramid of Djoser & 29.871397 & 31.216532 & 5 & 95 & \\
\hline Egypt, Saqqara, Pyramid of Khendjer & 29.832363 & 31.224043 & 0 & 90 & $\mathrm{E}$ \\
\hline Egypt, Saqqara, Pyramid of Pepi II & 29.840246 & 31.213496 & 0 & 90 & $\mathrm{E}$ \\
\hline Egypt, Saqqara, Pyramid of Qakare Ibi & 29.841590 & 31.217712 & -10 & 80 & \\
\hline Egypt, Saqqara, Pyramid of Unas & 29.868182 & 31.215012 & 0 & 90 & $\mathrm{E}$ \\
\hline Egypt, Saqqara, Pyramid Userkaf & 29.873332 & 31.219334 & 0 & 90 & $\mathrm{E}$ \\
\hline Egypt, Shunet El Zebib & 26.189510 & 31.908055 & -41.7 & 48.3 & \\
\hline Egypt, Siwa Oasis, Amun Temple & 29.201375 & 25.516151 & & & \\
\hline Egypt, Temple of Edfu & 24.978092 & 32.873475 & 3 & 93 & \\
\hline Egypt, Temple of Esna & 25.293444 & 32.556125 & -23 & 67 & $M$ \\
\hline Egypt, Temple of Hathor, El Kab & 25.138586 & 32.828651 & -44 & 46 & \\
\hline Egypt, Temple of Isis at Shenhur & 25.861040 & 32.776808 & 10 & 100 & \\
\hline Egypt, Temple of Ramses II & 25.727588 & 32.610283 & 41 & 131 & \\
\hline Egypt, Zawyet El Aryan, Layer Pyramid & 29.932820 & 31.161262 & -12 & 78 & \\
\hline Ethiopia, Bete Giyorgis & 12.031714 & 39.041190 & 5.8 & 95.8 & $\mathrm{~m}$ \\
\hline Ethiopia, Yeha Temple & \begin{tabular}{|l|}
14.285703 \\
\end{tabular} & 39.019114 & 11.4 & 101.4 & \\
\hline Sudan, Dangeil, Amun Temple & 18.131307 & 33.959800 & 16.5 & 106.5 & \\
\hline
\end{tabular}

$\mathrm{E}=$ cardinal directions, i.e. geographic poles, and equinoxes. $\mathrm{M}, \mathrm{m}=$ major and minor lunar standstills. $\mathrm{S}$ = solstices. $\mathrm{st}$ = stellar alignments (aligned to Alkaid in Ursa Major). 
with this conclusion. The Temple of Hathor at Dendera was very likely aligned to the star Alkaid in the constellation Ursa Major, which is associated with the Egyptian goddess Hathor.

If no alignment is given, the explanation is unknown. In some cases, there may be more than one explanation for an alignment.

\section{Asia}

Table 2 lists sites examined in Asia. Many of the sites in China considered here are ancient earthen mounds that are aligned either to the cardinal directions or thought to have been aligned in the direction of the magnetic pole at the time of construction (Charvátová et al., 2011). Some of the sites considered in Thailand are temples that could also have been aligned to the north geomagnetic pole (lyemori et al., 2011). Magli (2016) determined that a very clear pattern of cardinal orientation and alignment occurs in numerous temples in and around Angkor. Although some sites appear to reference the solstices in their construction and many are aligned to one another in solstitial directions, none of the sites themselves are aligned to the solstices. Unlike in Egypt, we were unable to find any sites in Asia oriented to solstices. Several were oriented, however, in directions that correspond to lunar standstills. Three sites located in the Tropic of Cancer might have been aligned to the sun on so-called "zenith passage days" when the sun passes directly overhead. McKim Malville (2015) analyzed 31 sites in India and found that two-thirds were aligned to the cardinal directions, solstices, and zenith passages. About half of the sites examined in other parts of India did not have an obvious explanation for their alignment.

\section{Europe}

Table 3 shows the alignments of ancient sites in Europe. Unlike Africa with many of its sites aligned in the cardinal directions and Asia with many of its sites aligned either to true (geographic) north or geomagnetic north, about half of the sites examined in Europe are aligned to solstices and lunar standstills. Palantine Hill, which was the earliest settlement in ancient Rome, is aligned to major lunar standstills. The Parthenon, which sits atop the Acropolis, is not aligned to solstices or to lunar standstills. Dinsmoor proposed that it was aligned to the 
TABLE 2

\section{Alignments of Sites in Asia}

\begin{tabular}{|c|c|c|c|c|c|c|}
\hline Cambodia, Koh Ker & 13.783220 & 104.537453 & -12.5 & 77.5 & $\mathrm{z}$ & \\
\hline \begin{tabular}{|l|} 
Cambodia, Preah Khan of Kompong Svay \\
\end{tabular} & 13.403820 & 104.754210 & -28.2 & 61.8 & $M$ & \\
\hline China, Chongling Mausoleum of Emperor Dezong of Tang & 34.707380 & 108.828530 & -4.2 & 85.8 & $x$ & Aligns to geo-magnetic pole around $400 \mathrm{CE}$ \\
\hline \begin{tabular}{|c|} 
China, Jinling Mausoleum of Emperor Xianzong of Tang \\
\end{tabular} & 34.570992 & 108.265923 & -9 & 81 & $x$ & Aligns to geo-magnetic pole around $600 \mathrm{CE}$ \\
\hline China, The Lianhu Altar & 36.632869 & 101.746123 & 15.8 & 105.8 & s & NE-SW diagonal aligned to solstice \\
\hline China, Tomb of Consort Ban & 34.379801 & 108.704492 & -11 & 79 & & \\
\hline China, Tomb of Emperor Ai of Han & 34.400855 & 108.764606 & 0 & 90 & E & \\
\hline China, Tomb of Emperor Cheng of Han & 34.374896 & 108.698001 & -10 & 80 & $x$ & Aligns to geo-magnetic pole around $900 \mathrm{CE}$ \\
\hline China, Tomb of Emperor Gaozu of Han & 34.434691 & 108.876647 & -14 & 76 & & \\
\hline \begin{tabular}{|l|} 
China, Tomb of Emperor Hui of Han \\
\end{tabular} & 34.422895 & 108.841317 & -17 & 73 & & \\
\hline China, Tomb of Emperor Jing of Han & 34.443823 & 108.940784 & 0 & 90 & E & \\
\hline China, Tomb of Emperor Ping of Han & 34.397774 & $\mid 108.712421$ & 0 & 90 & $\mathrm{E}$ & \\
\hline China, Tomb of Emperor Wen of Sui & 34.287850 & 108.022890 & -3 & 87 & $x$ & Aligns to geo-magnetic pole around $400 \mathrm{CE}$ \\
\hline China, Tomb of Emperor Wu of Han & 34.338085 & 108.569684 & -8 & 82 & $\hat{x}$ & Aligns to geo-magnetic pole around $700 \mathrm{CE}$ \\
\hline China, Tomb of Emperor Xuan of Han & 34.181063 & 109.022312 & 0 & 90 & $\hat{E}$ & \\
\hline China, Tomb of Emperor Yuan of Han & 34.390303 & 108.739114 & 0 & 90 & E & \\
\hline China, Tomb of Emperor Zhao of Han & 34.361753 & 108.640108 & -11 & 79 & $x$ & Aligns to geo-magnetic pole around $800 \mathrm{CE}$ \\
\hline China, Tomb of Empress Dou & 34.235825 & 109.118614 & 22.6 & 112.6 & $\mathrm{~m}$ & \\
\hline China, Tomb of Empress Dowager Bo & 34.220993 & 109.096341 & 21.6 & 111.6 & $\mathrm{~m}$ & \\
\hline China, Tomb of Empress Fu & 34.402608 & 108.772545 & -4 & 86 & $x$ & Aligns to geo-magnetic pole around $1000 \mathrm{CE}$ \\
\hline \begin{tabular}{|l|} 
China, Tomb of Empress Li \\
\end{tabular} & 34.340327 & 108.562002 & -9.5 & 80.5 & $x$ & Aligns to geo-magnetic pole around $800 \mathrm{CE}$ \\
\hline China, Tomb of Empress Lü & 34.433824 & 108.881292 & -10.2 & 79.8 & s & NW-SE diagonal aligned to solstice \\
\hline China, Tomb of Empress Shangguan & 34.363135 & 108.630538 & -8 & 82 & $x$ & Aligns to geo-magnetic pole around $900 \mathrm{CE}$ \\
\hline China, Tomb of Empress Wang (a) & 34.393242 & 108.733835 & 0 & 90 & E & \\
\hline China, Tomb of Empress Wang (b) & 34.446291 & 108.947500 & 0 & 90 & E & \\
\hline China, Tomb of Empress Wang (c) & 34.178951 & 109.028396 & 0 & 90 & E & \\
\hline China, Tomb of Empress Xu (a) & 34.374648 & 108.684740 & -9.5 & 80.5 & $x$ & Aligns to geo-magnetic pole around $800 \mathrm{CE}$ \\
\hline China, Tomb of Empress Xu (b) & 34.127340 & 109.055786 & 0 & 90 & E & \\
\hline China, Tomb of Empress Zhang Yan & 34.423195 & 108.836961 & -15 & 75 & & \\
\hline China, Tomb of Marquis Zhang Ao & 34.427745 & 108.851209 & -15 & 75 & & \\
\hline China, Tomb of Princess Chengyang of Emperor Taizong & 34.615600 & 108.493140 & -6 & $\frac{84}{84}$ & $x$ & Aligns to geo-magnetic pole around 500 \\
\hline China, Tomb of Princess Xincheng of Emperor Taizong & 34.623650 & 108.498880 & -21 & 69 & & \\
\hline China, Yarnaz Valley, Yarkhoto & $\mid 42.952022$ & 89.061138 & -40 & 50 & M & \\
\hline India, Amritsar, Golden Temple & 31.619938 & 74.876511 & 33.2 & $\mid 123.2$ & M & \\
\hline India, Chidambaram, Chidambaram Nataraja & 11.399234 & 79.693715 & -1 & 89 & E & \\
\hline India, Chitoor, Srikalahasti Temple & 13.749686 & 79.698308 & 0 & 90 & E & \\
\hline India, Kanchipura, Ekambareswarar Temple & 12.847302 & 79.699525 & 18.3 & 108.3 & $\mathrm{~m}$ & \\
\hline India, Khadirbet, Dholavira & 23.886907 & 70.213776 & -5 & 85 & & \\
\hline India, Madhya Pradesh, Sas Bahu Temple & 16.018856 & 75.881959 & -4 & 86 & & \\
\hline India, Madhya Pradesh, Tigawa Temple & 23.690196 & 80.066918 & -10 & 80 & & \\
\hline India, Mahabalipuram, Shore Temple & 12.616492 & 80.199267 & 13 & 103 & $z$ & \\
\hline India, Rameshwar Mandir & 16.217680 & 73.462012 & -14 & 76 & & \\
\hline India, Shri Martand Sun Temple & 33.745588 & 75.220286 & -13.9 & 76.1 & & \\
\hline India, Sigiriya & 7.957173 & 80.760031 & 8.3 & 98.3 & 2 & \\
\hline India, Tamil Nadu & & & & & $E, S, Z$ & Malville's analysis of 31 temples (see text). \\
\hline India, Thanjavur, Brihadisvara Temple & 10.782614 & 79.131735 & -20.5 & 69.5 & st, $m$ & Aligned toward Pleiades at the time of construction \\
\hline India, Tiruvannamalai, Annamalaiyar Temple & 12.231884 & 79.066790 & 11.4 & 101.4 & $z$ & \\
\hline India, Udaipur Rajasthan, Sas Bahu Temple & 24.735191 & 73.716283 & -16 & 74 & & \\
\hline $\begin{array}{l}\text { India, Venkateswara Temple } \\
\end{array}$ & 13.683250 & 79.347195 & -7 & 83 & & \\
\hline Indonesia, Gunung Padang & -6.994518 & 107.056383 & -20 & 70 & & \\
\hline $\begin{array}{l}\text { Inner Mongolia, Xanadu } \\
\end{array}$ & 42.356388 & 116.184304 & 0 & 90 & $\mathrm{E}$ & \\
\hline Japan, Osaka Castle & 34.687298 & 135.525826 & 5.7 & 95.7 & & \\
\hline Maldives, Thinadhoo & 0.530107 & 72.997170 & 43 & 133 & D & Oriented in the direction of Petra \\
\hline Pakistan, Harappa & 30.628104 & 72.863909 & 0 & $\mid 90$ & E & \\
\hline Russia Por-Bazhyn & 50.615271 & 97.384872 & 9.5 & 99.5 & & \\
\hline Thailand Angkor Wat & 13.412469 & 103.866986 & 0 & 90 & E & \\
\hline Thailand, Ayutthaya, Wat Phra Mahathat & 14.356943 & 100.567509 & -5.3 & 84.7 & $x$ & Aligns to geo-magnetic pole around $900 \mathrm{CE}$ \\
\hline Thailand, Kao Klang Nai, Sri Thep & 15.465521 & \begin{tabular}{|l|l|}
01.144681 \\
\end{tabular} & 9.5 & 99.5 & & \\
\hline Thailand, Prasat Hin Phimai & 15.220930 & 102.493861 & -22 & 68 & & \\
\hline Thailand, Prasat Mueang Tam & 14.496089 & 102.982608 & -11 & 79 & & \\
\hline Thailand, Prasat Phanom Rung & 14.532044 & 102.940223 & -5.5 & 84.5 & $x$ & Aligns to geo-magnetic pole around $600 \mathrm{CE}$ \\
\hline Thailand, Prasat Si Khoraphum & 14.944574 & 103.798352 & 0 & 90 & E & \\
\hline Thailand, Wat Phra Sri Rattana Mahathat & 14.798673 & 100.613862 & 0 & 90 & E & \\
\hline
\end{tabular}

$\mathrm{D}=$ alignments to "sacred directions". $\mathrm{E}=$ cardinal directions, i.e. geographic poles, and equinoxes. $M, m=$ major and minor lunar standstills. $S=$ solstices. $s t=$ stellar alignments. $X=$ magnetic pole at the time of construction. $Z=$ zenith passage. 
TABLE 3

Alignments of Sites in Europe

\begin{tabular}{|l|l|l|l|l|l|l|}
\hline Bosnia, Pyramid of the Sun & 43.977259 & 18.176514 & 8.4 & 98.4 & & Artificiality not established \\
\hline Greece, Athens, The Parthenon & 37.971517 & 23.726590 & -13.5 & 76.5 & & Aligned to sunrise on Athena's birthday \\
\hline Greece, Delphi Amphitheater & 38.482477 & 22.500577 & -38.2 & 51.8 & $\mathrm{D}$ & Oriented in the direction of Knossos \\
\hline Greece, Knossos & 35.297863 & 25.163092 & 11.8 & 101.8 & & Adjusted equinox algnment \\
\hline Greece, Mycenae, Lion Gate & 37.730752 & 22.756500 & -40 & 50 & & Aligned to topography \\
\hline Greece, Mycenae, Tomb of Agamemnon & 37.726725 & 22.754367 & 10.5 & 100.5 & & Aligned to topography \\
\hline Greece, The Temple of Artemis & 37.949611 & 27.363921 & 21 & 111 & & \\
\hline Italy, Rome, Circus Maximus & 41.885944 & 12.485215 & 36.7 & 126.7 & $\mathrm{M}$ & \\
\hline Italy, Rome, Palantine Hill & 41.889209 & 12.487459 & 36.7 & 126.7 & $\mathrm{M}$ & \\
\hline Italy, Sardinia, Monte d'Accoddi & 40.790754 & 8.448908 & 9.1 & 99.1 & & \\
\hline Malta, Gozo, Ggantija Temple & 36.047260 & 14.269015 & 37 & 127 & $\mathrm{M}$ & \\
\hline Spain, Mosque-Cathedral of Cordoba & 37.878906 & -4.779387 & -30.4 & 59.6 & $\mathrm{~S}$ & \\
\hline Spain, Naveta d'Es Tudons & 40.003075 & 3.891653 & -19.2 & 70.8 & $\mathrm{~m}$ & \\
\hline Turkey, Hagia Sophia & 41.013140 & 28.983182 & 34.3 & 124.3 & $\mathrm{~S}$ & \\
\hline Turkey, Hattusa & 40.019943 & 34.615455 & 38 & 128 & $\mathrm{M}$ & \\
\hline UK, Calanais Standing Stones & 58.197566 & -6.745127 & & & & \\
\hline UK, Glastonbury Tor & 51.144444 & -2.698611 & -26.5 & 63.5 & $\mathrm{~m}$ & \\
\hline UK, Stonehenge & 51.178868 & -1.826163 & & & $\mathrm{~S}, \mathrm{M}, \mathrm{m}$ & \\
\hline
\end{tabular}

$\mathrm{D}=$ alignments to "sacred directions". $\mathrm{M}, \mathrm{m}=$ major and minor lunar standstills. $\mathrm{S}=$ solstices.

sunrise on the birthday of the Greek goddess Athena (Hannah, 2013). That the Acropolis also appears aligned in the same general direction and predates the Parthenon by hundreds, perhaps thousands, of years would seem to challenge that dating and the reason for its alignment. Maravelia (2002) proposes that the alignment of a number of tholus tubes in Mycenae are based on topographical not astronomical considerations.

\section{North America}

Most of the Native American/indigenous sites examined in North America are aligned to the cardinal directions, solstices, or lunar standstills (Table 4).

\section{TABLE 4}

\section{Alignments of Sites in North America}

\begin{tabular}{|l|l|l|l|l|l|l|}
\hline Canada, AB, Badlands Guardian & 50.010370 & -110.113133 & & & E & Geoglyph aligned to north. Artificiality not established \\
\hline US, California, Blythe Intaglios, B1 & 33.800585 & -114.532055 & 0 & 90 & E & Geoglyph aligned to north \\
\hline US, California, Blythe Intaglios, B3 & 33.800402 & -114.538078 & 29 & 119 & & \\
\hline US, Georgia, Ocmulgee National Monument & 32.838868 & -83.606114 & 34 & 124 & M & \\
\hline US, New Mexico, Chaco Canyon, Pueblo del Arroyo & 36.060854 & -107.966300 & 24 & 114 & M & \\
\hline US, Ohio, Great Serpent Mound & 39.026420 & -83.431091 & 27.7 & 117.7 & S & "Head" faces solstice \\
\hline US. Illinois, Cahokia, Monks Mound & 38.660158 & -90.062466 & & & S,M & \\
\hline
\end{tabular}

$E=$ Cardinal directions, i.e. geographic poles, and equinoxes. $M=$ major lunar standstills. $\mathrm{S}=$ solstices. 


\section{Pacific Ocean}

About half of the sites in the Pacific appear to have astronomical alignments (Table 5). The Ahu platforms on which the Easter Island Moai look out to the sea were built in a variety of orientations around the island. Three of the alignments may be astronomical. The Temple of Nan Dawas at Nan Madol in Micronesia is aligned in the direction of the zenith passage sunrise. A megalithic structure called the Ha'amonga'a Maui Trilithon along with most of the structures on the island of Tonga are aligned in a northeast direction that has no known explanation.

TABLE 5

\section{Alignments of Sites in the Pacific Ocean}

\begin{tabular}{|l|l|l|l|l|l|}
\hline Chile,Easter Island, Ahu Akivi & -27.115014 & -109.395043 & -2.7 & 87.3 & E \\
\hline Chile,Easter Island, Ahu Nau Nau & -27.074425 & -109.322455 & -19.6 & 70.4 & $\mathrm{~m}$ \\
\hline Chile,Easter Island, Ahu Tahai & -27.140076 & -109.427314 & 8.3 & 98.3 & \\
\hline Chile,Easter Island, Ahu Tongariki & -27.125774 & -109.276933 & 30 & 120 & $\mathrm{~S}$ \\
\hline Chile,Easter Island, Ahu Vinapu & -27.174098 & -109.405737 & 8.1 & 98.1 & \\
\hline Micronesia, Nan Madol & 6.844537 & 158.335795 & -33 & 57 & $\mathrm{M}$ \\
\hline Micronesia, Nan Madol, Temple of Nan Dawas & 6.844537 & 158.335795 & 7 & 97 & $Z$ \\
\hline Samoa, Pulemelei Mound & -13.735237 & -172.324399 & -7.3 & 82.7 & \\
\hline Tonga, Ha'amonga 'a Maui Trilithon & -21.136606 & -175.048087 & 32.7 & 122.7 & $\star$ \\
\hline
\end{tabular}

* Entire island of Tonga aligned in the same direction. $\mathrm{E}=$ cardinal directions, i.e. geographic poles, and equinoxes. $\mathrm{M}, \mathrm{m}=$ major and minor lunar standstills. $\mathrm{S}=$ solstices. $\mathrm{Z}=$ zenith passage.

\section{The Middle East}

Only four of the sites examined in the Middle East have an apparent explanation for their alignment (Table 6). The Kaaba in Mecca analyzed in detail by Hawkins and King (1982) was found to be most accurately aligned to the moon, which is one of several directions or qibla that are sacred in Islam. The Ziggurat of Ur (Sparavigna, 2016) and the Great Mosque of Sana'a in Yemen also are aligned to the moon. The Dome of the Rock in Jerusalem is oriented toward Petra in Jordan.

\section{South America}

About a third of the sites examined in South America are aligned to the cardinal directions, solstices, or lunar standstills (Table 7). Another third appear to be aligned to face either the city of Cuzco in Peru's Sacred Valley or the city of Caral in the Supe Valley. A number of lines 
TABLE 6

Alignments of Sites in the Middle East

\begin{tabular}{|l|l|l|l|l|l|}
\hline Iran, Chogha Zanbil & 32.008997 & 48.521593 & -43.5 & 46.5 & \\
\hline Iraq, Dur-Kurigalzu & 33.353671 & 44.202164 & -39.6 & 50.4 & \\
\hline Iraq, Tower of Babel & 32.536284 & 44.420803 & -11.3 & 78.7 & \\
\hline Iraq, Ziggurat of Ur & 30.962711 & 46.103126 & -33.3 & 56.7 & $\mathrm{M}$ \\
\hline Jerusalem, Dome of the Rock & 31.778087 & 35.235306 & -7.3 & 82.7 & $\mathrm{D}$ \\
\hline Jerusalem, Western Wall & 31.776657 & 35.234470 & -12.1 & 77.9 & \\
\hline Jordan, Petra, Temple of the Winged Lions & 30.330297 & 35.442554 & 17.5 & 107.5 & \\
\hline Jordan, Qasr II-Abd, Irak Al-Amir & 31.912785 & 35.751941 & -15 & 75 & \\
\hline Jordan, Umayyad Mosque in Amman & 33.511593 & 36.306657 & -6.4 & 83.6 & \\
\hline Lebanon, Baalbek, Temple of Jupiter & 34.006694 & 36.203826 & -12.2 & 77.8 & \\
\hline Saudi Arabia, Mecca, Kaaba & 21.422510 & 39.826174 & -34.9 & 55.1 & $\mathrm{M}$ \\
\hline Turkey, Harran & 36.865021 & 39.031565 & 9.6 & 99.6 & \\
\hline Yemen, Great Mosque of Sana'a & 15.353123 & 44.214876 & -25 & 65 & $\mathrm{M}$ \\
\hline
\end{tabular}

* Oriented in the direction of Petra. $D=$ alignments to "sacred directions". $M=$ major lunar standstills.

\section{TABLE 7}

\section{Alignments of Sites in South America}

\begin{tabular}{|c|c|c|c|c|c|c|}
\hline Bolivia, Chincana Labyrinth & -15.990127 & -69.202952 & 44 & 134 & D & Oriented in the direction of Cuzco \\
\hline Bolivia, Puma Punku & -16.561720 & -68.680046 & 2 & 92 & & \\
\hline Bolivia, Quenuani & -16.259407 & -69.171270 & -20 & 70 & s & \\
\hline Bolivia, Tiwanaku & -16.554933 & -68.673487 & 2 & 92 & & \\
\hline Peru, Caral-Supe & -10.893458 & -77.520540 & 19.5 & 109.5 & s & Oldest city in the Americas \\
\hline Peru, Caral-Supe, Huanca Pyramid & -10.893458 & -77.520540 & 19.5 & 109.5 & & \\
\hline Peru, Chan Chan & -8.103554 & -79.070760 & 19.5 & 109.5 & $\mathrm{~m}$ & Name "Chan Chan" may refer to sun or moon \\
\hline Peru, Chavin & -9.594527 & -77.177002 & 14.7 & 104.7 & D & Oriented in the direction of Caral-Supe \\
\hline Peru, Cuzco & -13.518587 & -71.975952 & & & & Center of Quechua ceques or pathways \\
\hline Peru, Huanuco Pampa & -9.875388 & -76.816395 & 0 & 90 & $\mathrm{E}$ & \\
\hline Peru, Huayna Picchu, Temple of the Moon & -13.151931 & -72.546507 & & & M & Faces north to view full range of lunar motion \\
\hline Peru, La Centinela & -13.450075 & -76.172233 & 5.6 & 95.6 & & \\
\hline Peru, Machu Picchu, Temple of the Three Windows & -13.163592 & -72.545414 & -34.7 & 55.3 & & \\
\hline $\begin{array}{l}\text { Peru, Machu Picchu, Terraces } \\
\end{array}$ & -13.164219 & -72.544831 & -25 & $\mid 65$ & & Oriented in a solar direction \\
\hline Peru, Marcahuasi, Face & -11.775670 & -76.581853 & 43 & 133 & D & Oriented in the direction of Caral-Supe \\
\hline Peru, Nazca Lines & -14.712825 & -75.174850 & 19.3 & 109.3 & D & Oriented in the direction of Cuzco \\
\hline Peru, Ollantaytambo, Temple of the Sun & -13.257536 & -72.267129 & -35 & 55 & & \\
\hline Peru, Sacsahuaman & -13.509330 & -71.980916 & & & D & "Head" of a puma represented by the city of Cuzco \\
\hline Peru, Sechin Bajo & -9.464809 & -78.265259 & -25.5 & 64.5 & s & \\
\hline Peru, Warawtampu & -10.465490 & -76.536647 & -24.2 & 65.8 & D & Oriented in the direction of Caral-Supe \\
\hline \begin{tabular}{|l|l} 
Peru. Chotuna \\
\end{tabular} & -6.720363 & -79.952796 & 0 & 90 & E & \\
\hline
\end{tabular}

$\mathrm{D}=$ alignments to "sacred directions". $\mathrm{E}=$ cardinal directions, i.e. geographic poles, and equinoxes. $\mathrm{M}, \mathrm{m}=$ major and minor lunar standstills. $\mathrm{S}=$ solstices.

and geoglyphs in Nazca appear to point toward, away from, or at right angles to Cuzco. The alignment of sites to Cuzco is consistent with a set of directions that emanate from Cuzco called ceques. The remainder of the sites in South America have no obvious explanation for their alignment, including the large megalithic structures at Machu Picchu, Olantaytambo, Tiwanaku, and Puma Punku, whose origins are poorly understood. 


\section{Mesoamerica}

In analyzing the alignments of Mayan sites, Aveni found that 16 percent are aligned west of north, while the other 86 percent are aligned east of north (Aveni, 2001). He concludes that an eastern skew was a standard architectural practice over a wide area in Mexico. A peak around $25^{\circ}$ south of east suggests that many sites were aligned to solstices. As shown in Table 8, more than 75 percent of identified alignments lie in solar or lunar directions. What is particularly interesting about Mesoamerica is the large fraction of sites whose alignments are unknown. Fuson (1969) suggested the possibility that Mayan temples were aligned to magnetic north using a compass. Carroll (1979) analyzed about four dozen Mesoamerican sites and found that almost all of them were not aligned to magnetic north, based on their assumed date of construction.

TABLE 8

\section{Alignments of Sites in Mesoamerica}

\begin{tabular}{|c|c|c|c|c|c|c|}
\hline Belize, Altun Ha, Sun God Pyramid & 17.763950 & -88.347061 & 7.6 & 97.6 & & \\
\hline \begin{tabular}{|l|} 
Belize, Xunantunich \\
\end{tabular} & 17.088922 & -89.141631 & -10.3 & 79.7 & D & Oriented in the direction of Uxmal \\
\hline EI Salvador, Tazumal & 13.979547 & -89.674131 & 18 & 108 & $\mathrm{~m}$ & \\
\hline Guatemala, Mixco Viejo & 14.871668 & -90.664167 & 12.5 & 102.5 & D & Oriented in the direction of Uxmal \\
\hline Guatemala, Tikal & 17.222094 & -89.623614 & 8.6 & 98.6 & & \\
\hline Guatemala, Yaxchilan & 16.899655 & -90.967093 & 30.4 & 120.4 & D & Oriented in the direction of Chichen Itza \\
\hline Honduras, Copan, Step Pyramids & 14.840000 & -89.140000 & & & $\frac{u}{z}$ & Multiple orientations between -4 and $+4 \mathrm{deg}$. \\
\hline Mexico, Acatitlan & 19.550000 & -99.170000 & 20.3 & 110.3 & $z$ & \\
\hline Mexico, Alta Vista & 23.478544 & -103.945607 & & & & Multiple alignments \\
\hline Mexico, Bonampak & 16.704000 & -91.065000 & 38 & 128 & & \\
\hline Mexico, Calakmul & 18.105392 & -89.810829 & 8.8 & 98.8 & & \\
\hline Mexico, Calixtlahuaca & 19.335038 & -99.697570 & -30 & 60 & M & \\
\hline Mexico, Chalcatzingo & 18.676715 & -98.770783 & 6.8 & 96.8 & & \\
\hline Mexico, Chichen Itza & 20.680000 & -88.570000 & 21 & 111 & $M, Z$ & Also cenotes, crop cycles, Venus $\mathrm{min} / \mathrm{max}$ settings \\
\hline Mexico, Chimalacatlan, C1 & 18.446236 & -99.105878 & -34.7 & 55.3 & $\mathrm{M}$ & \\
\hline Mexico, Chimalacatlan, C2 & 18.444804 & -99.104331 & 28.7 & 118.7 & $\mathrm{~m}$ & \\
\hline Mexico, Cholula & 19.058305 & -98.301906 & 25 & 115 & s & \\
\hline Mexico, Coba, Grand Pyramid & 20.492974 & -87.724195 & -39 & 51 & & \\
\hline Mexico, Comalcalco & 18.278200 & -93.200327 & 24 & 114 & S & \\
\hline Mexico, Cuauhtinchan Archeological Site, Cuauhcalli & 18.953500 & -99.502888 & 15.4 & 105.4 & $\mathrm{~m}$ & \\
\hline Mexico, Cuicuilco & $\frac{19.30501021}{19.3010}$ & -99.183798 & & & & Circular structure \\
\hline Mexico, El Cerrito Archaological Zone & 20.551376 & -100.444027 & 7.4 & 97.4 & & \\
\hline Mexico, El Tajin, Pyramid of the Niches & 20.448058 & -97.378242 & 14.5 & 104.5 & & \\
\hline Mexico, El Tajin, Southern Ballcourt & 20.448058 & -97.378242 & 0 & 90 & $\mathrm{E}$ & \\
\hline Mexico, El Tajin, Tajin Chico & 20.448058 & -97.378242 & 40 & 130 & & \\
\hline Mexico, El Tepozteco & 19.000786 & -99.101558 & 26 & 116 & $\mathrm{~m}$ & \\
\hline Mexico, La Venta & 18.103191 & -94.040946 & -12.2 & 77.8 & D & Oriented in the direction of Comalcalco \\
\hline Mexico, Mayapan & 20.629823 & -89.460590 & & & & Multiple orientations between -5 and $+10 \mathrm{deg}$. \\
\hline Mexico, Mitla & 16.927049 & -96.359348 & 12 & 102 & & \\
\hline Mexico, Monte Alban & 17.042122 & -96.768184 & 6.45 & 96.45 & & \\
\hline Mexico, Monte Alban, Building J & 17.042122 & -96.768184 & -43 & 47 & st & Aligned to Capella, points to Building P with zenith tube. \\
\hline Mexico, Palenque, North Group & 17.483978 & -92.046320 & 10.1 & 100.1 & & \\
\hline Mexico, Palenque, Temple of the Inscriptions & 17.480000 & -92.050000 & 20.6 & 110.6 & & \\
\hline Mexico, Tenango & 19.108425 & -99.597693 & 14 & 104 & & Multiple orientations between 12 to $16 \mathrm{deg}$. \\
\hline Mexico, Tenochtitlan & 19.435000 & -99.131389 & 7 & 97 & & Adjusted equinox algnment \\
\hline Mexico, Teotihuacan & 19.692500 & -98.843889 & 15.6 & 105.6 & st & Pleiades. Also mountains, pecked crosses, 260 day cycle \\
\hline Mexico, Tiatelolco & 19.450994 & -99.137510 & 8.5 & 98.5 & & \\
\hline Mexico, Tula & 20.064451 & -99.340500 & 15.47 & 105.47 & $\mathrm{~m}$ & \\
\hline Mexico, Tulum & 20.210000 & -87.430000 & 22.3 & 112.3 & & \\
\hline Mexico, Uxmal, Palace of the Governors & 20.359444 & $\begin{aligned}-01.450000 \\
-89.771389\end{aligned}$ & $\frac{2-30}{30}$ & $\frac{1120}{120}$ & s & Most southern Venus rise, $750 \mathrm{CE}$ \\
\hline Mexico, Uxmal, Pyramid of the Magician & 20.359444 & -89.771389 & 9.2 & 99.2 & & \\
\hline Mexico, Uxmal, Templo Mayor & 20.359444 & -89.771389 & 19.6 & 109.6 & 2 & \\
\hline Mexico, Xochicalco, Grand Pyramid & 18.803889 & 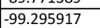 & 0 & 90 & $\frac{L}{E}$ & \\
\hline Mexico, Xochicalco, Temple of Quetzalcoatl & 18.803889 & -99.295917 & 15.4 & 105.4 & & \\
\hline
\end{tabular}




\section{ANALYSIS OF ALIGNMENTS}

The graphs in Figure 6 plot the distribution of site alignments within each of the eight geographic regions. Site distributions are con-

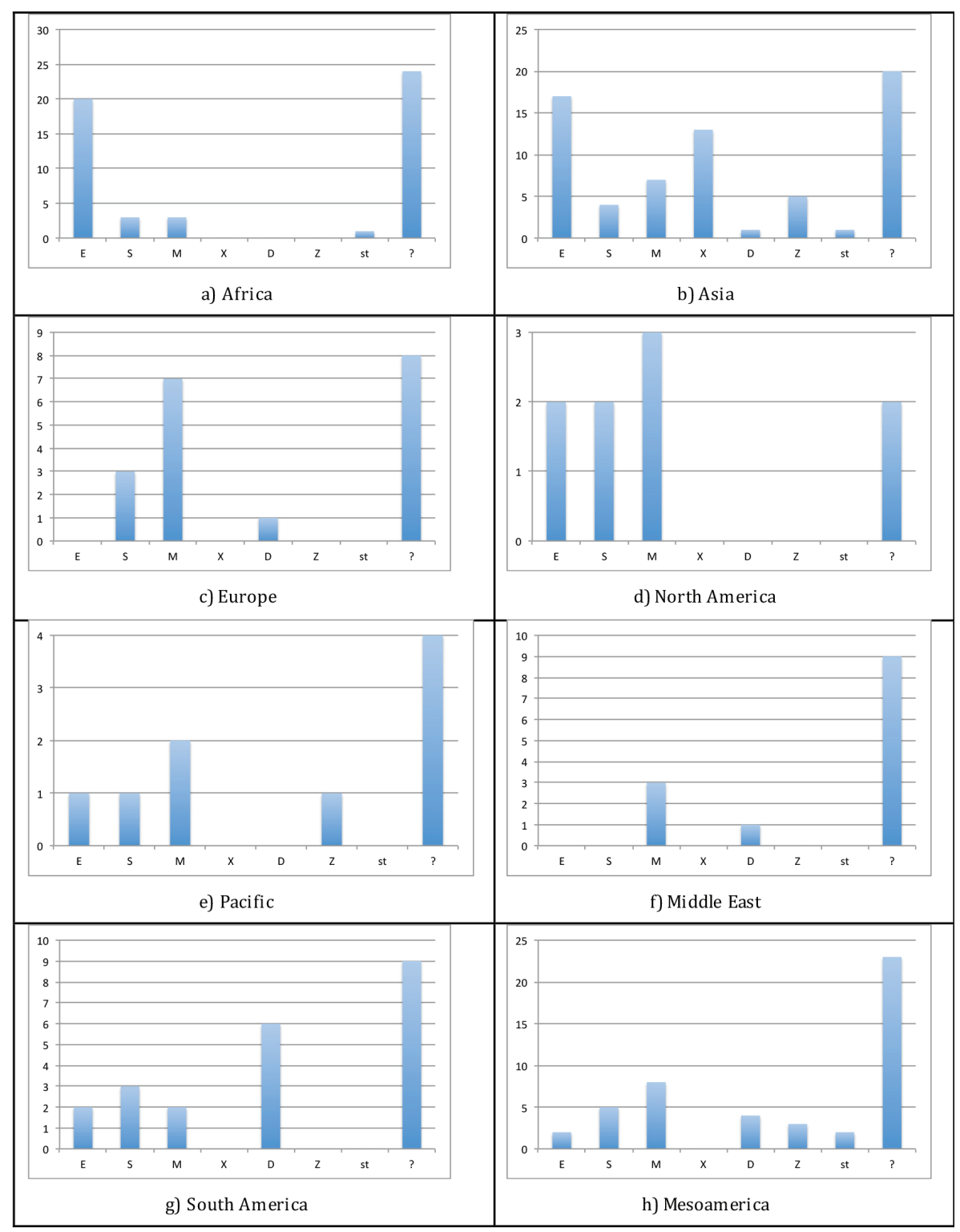

Figure 6. Site-alignment distributions. 


\section{TABLE 9}

\section{Region-to-Region Similarity (Euclidean Distances) Based on Similarity of Site-Alignment Distributions}

\begin{tabular}{|l|l|l|l|r|r|r|r|r|}
\hline & \multicolumn{1}{|l|}{ lfrica } & \multicolumn{1}{|l|}{ Asia } & Europe & North America & Pacific & Middle East & South America & Mesoamerica \\
\hline Africa & & 0.236314729 & 0.860343049 & 0.339688139 & 0.425130316 & 1.033093278 & 0.574979099 & 0.536565501 \\
\hline Asia & 0.236314729 & & 0.491470099 & 0.210654053 & 0.185381944 & 0.634548611 & 0.340786284 & 0.223090278 \\
\hline Europe & 0.860343049 & 0.491470099 & & 0.13324338 & 0.149421488 & 0.112603306 & 0.395618368 & 0.131227043 \\
\hline North America & 0.339688139 & 0.210654053 & 0.13324338 & & 0.055510204 & 0.329081633 & 0.308899891 & 0.106363379 \\
\hline Pacific & 0.425130316 & 0.185381944 & 0.149421488 & 0.055510204 & & 0.305 & 0.316686391 & 0.058472222 \\
\hline Middle East & 1.033093278 & 0.634548611 & 0.112603306 & 0.329081633 & 0.305 & & 0.477071006 & 0.253472222 \\
\hline South America & 0.574979099 & 0.340786284 & 0.395618368 & 0.308899891 & 0.316686391 & 0.477071006 & & 0.147209895 \\
\hline Mesoamerica & 0.536565501 & 0.223090278 & 0.131227043 & 0.106363379 & 0.0584722222 & 0.253472222 & 0.147209895 & \\
\hline
\end{tabular}

verted to probabilities (relative frequencies) over the set of alignments $\{E, S, M, X, D, Z, s t\}$ where " $M$ " represents both major and minor lunar standstills. If $\vec{r}(i)$ and $\vec{r}(j)$ are the alignment probabilities within two geographic regions, we define the similarity between the two regions by

$$
d(i, j)=\|\vec{r}(i)-\vec{r}(j)\|
$$

Table 9 lists similarities between regions in terms of their alignment probabilities.

Figure 7 depicts the similarity between geographic regions using a distance-preserving nonlinear mapping algorithm (Carlotto, 1993). Regions on the edge of the map are the most distinct from other regions in terms of their alignment statistics. For example, South America is different from the other regions in terms of the large number of sites that are aligned to other sites. Africa, mainly Egypt, is distinguished by its many pyramids aligned to the cardinal directions. Asia is unique in that most of its sites are aligned either to true north or to geomagnetic north. Most sites in Europe are aligned to solstices or lunar standstills, while sites in the Middle East are aligned only to the moon. Almost all of the sites in North America that were built by indigenous people are aligned to the sun or moon.

\section{DISCUSSION}

Across all eight geographic regions, $19 \%$ of the sites considered are aligned to the cardinal directions, $9 \%$ to solstices, $15 \%$ to lunar standstill, $5 \%$ to the geomagnetic pole at the time of construction, $5 \%$ to other sites, $4 \%$ to zenith passages, and $1 \%$ to stars. About $42 \%$ of the sites (95 out of 224) are anomalous in that they cannot be explained by 


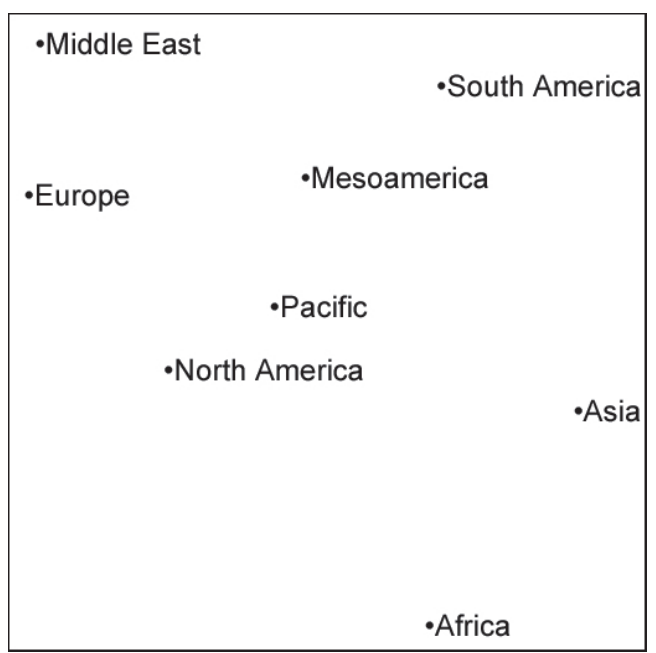

Figure 7. A 2-D map depicting similarities between geographic regions based on their site-distribution statistics.

any of our alignment hypotheses. Some of these sites may have aligned for other reasons, e.g., the alignment of the Parthenon to the sunrise on Athena's birthday or to conform to the landscape and topography as at Teotihuacan. Other structures such as Hindu temples in India (Daware, 2017) may have been aligned at the discretion of the builder without any obvious plan. It is also possible that some sites may not have been purposefully aligned at all.

That the alignment of so many sites cannot be explained is surprising. About half of the sites, on average, within all of the geographic regions (with the exception of North America) cannot be explained in terms of alignment (Figure 8). This would suggest that the reason for the non-alignment could be global and not local in nature. This possibility is considered in a subsequent paper.

\section{REFERENCES}

Aveni, A. F. (2001). Skywatchers: A revised and updated version of Skywatchers of Ancient Mexico. University of Texas Press.

Aveni, A. F., Calnek, E. E., \& Hartung, H. (1988, April). Myth, environment, and the orientation of the Templo Mayor of Tenochtitlan. American Antiquity, 53(2), 287-309. 


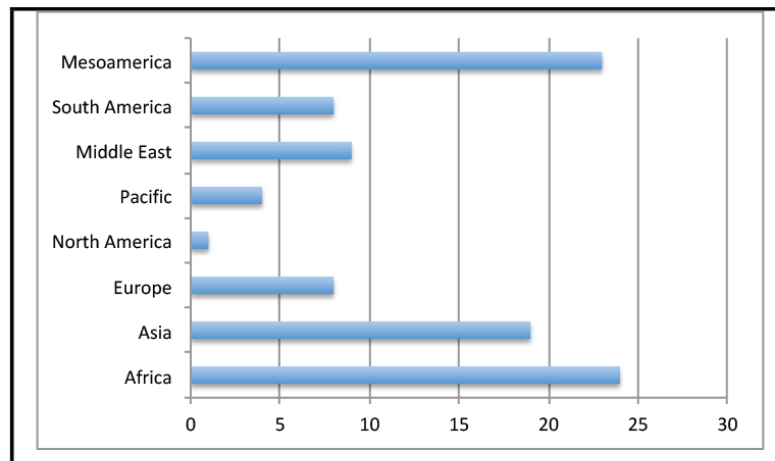

a) Unknown site counts

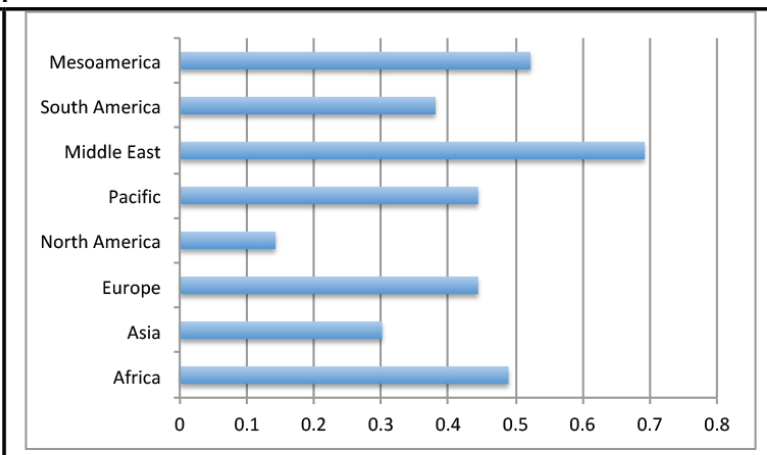

b) Unknown site relative frequencies

Figure 8. Geographic distributions of unknown-alignment sites.

Carlotto, M. J. (1994, June). Nonlinear mapping algorithm and applications for multidimensional data analysis. Journal of Visual Communication and Image Representation, 5(2), 127-138. https://doi.org/10.1006/jvci.1994.1012

Carroll, T. J. (1979). Were ancient Mesoamerican buildings oriented to magnetic north? [Bachelor's thesis, Massachusetts Institute of Technology]. http://hdl. handle.net/1721.1/68219

Charvátová, I., Klokočník, J., Kolmaš, J., \& Kostelecký, J. (2011, January). Chinese tombs oriented by a compass: Evidence from paleomagnetic changes versus the age of tombs. Studia Geophysica et Geodaetica, 55, 159-174. 494\{en-dash\}511. https://www.jstor.org/stable/2561728

Daware, A. R. (2017, May 24-28). Orientation of Hindu temples-India. International Conference on Science and Engineering for Sustainable Development, Bangkok, Thailand.

Fuson, R. H. (1969, September). The orientation of Mayan ceremonial centers. 
Annals of the Association of American Geographers, 59(3), 494-511. https:// www.jstor.org/stable/2561728

Hannah, R. (2013, December). Greek temple orientation: The case of the Older Parthenon in Athens. Nexus Network Journal, 15(3), 423-443. https://doi. org/10.1007/s00004-013-0169-1

Hardman, C., Jr., \& Hardman, M. H. (1987). The Great Serpent and the sun. Ohio Archaeologist, 37(3), 34-40. https://kb.osu.edu/handle/1811/55883

Hawkins, G. S. (1965). Stonehenge decoded. Doubleday.

Hawkins, G. S., \& King, D. A. (1982, June). On the orientation of the Kaaba. Journal for the History of Astronomy, 13(2), 102-109. https://doi. org/10.1177/002182868201300204

Iyemori, T., Hashizume, M., Saito, A., Nose, M., Choosakul, N., Tsuda, T., \& Odagi, Y. (2011). Geomagnetism and the orientation of temples in Thailand. Journal of the Siam Society, 99, 139149. http://www.siamese-heritage.org/jsspdf/2011/JSS_099_oj_Toshihiko_GeomagnetismAndOrientationOfTemples.pdf

King, D. A. (2018). Bibliography of books, articles, and websites on historical qibla determinations. https://www.davidaking.academia.edu/research

Krupp, E. C. (1994). Echoes of the ancient skies: The astronomy of lost civilizations. Dover.

Lehner, M. (1997). The complete pyramids: Solving the ancient mysteries. Thames \& Hudson.

Lepionka, M. E., \& Carlotto, M. J. (2015). Evidence of a Native American solar observatory on Sunset Hill in Gloucester, Massachusetts. Bulletin of the Massachusetts Archaeological Society, 76(1).

Lon, I. D. (2005). El sistema de ceques del Cuzco. http://www.monografias.com/ trabajos32/sistema-ceques/sistema-ceques.shtml

Magli, G. (2016). Archaeoastronomy in the Khmer heartland. https://arxiv.org/ abs $/ 1604.05674$

Maravelia, A.-A. (2002). The orientations of the nine tholos tombs at Mycenae. Journal for the History of Astronomy Supplement, 33 (Archaeoastronomy, 27), 63-66.

McElhinny, M. W., \& McFadden, P. L. (2000). Paleomagnetism: Continents and oceans. In R. Dmowska, J. R. Holton, \& H. T. Rossby (Eds.), International Geophysics, 73. Academic Press.

McKim Malville, J. M. (2015). Astronomy of Indian cities, temples, and pilgrimage centers. In C. L. N. Ruggles (Ed.), Handbook of archaeoastronomy and ethnoastronomy (pp. 1969-1980). Springer.

Ridderstad, M. (2009). Evidence of Minoan astronomy and calendrical practices. https://arxiv.org/pdf/o910.4801.pdf

Shaltout, M., \& Belmonte, J. A. (2005). On the orientation of ancient Egyptian temples: (1) Upper Egypt and Lower Nubia. Journal for the History of Astronomy, 36-3(124), 273-298. https://doi.org/10.1177/002182860503600302

Sparavigna, A. C. (2013). Sunrise and sunset azimuths in the planning of ancient Chinese towns. International Journal of Sciences, 2(11), 52-59. https://doi. org/10.18483/ijSci.334

Sparavigna, A. C. (2016, June 18). A ziggurat and the moon. Philica, Article 618. https://ssrn.com/abstract=2797629 